\title{
Elemental Sulfur Reduces to Sulfide in Black Layer Soil
}

William L. Berndt ${ }^{1}$ and Joseph M. Vargas, Jr. Division of Professional and Technical Studies, Edison College, 8099 College Parkway S.W., P.O. Box 60210, Building C-101, Fort Myers, FL 33906-6210; and the Department of Botany and Plant Pathology, 102 Pesticide Research Center, Michigan State University, East Lansing, MI 48824

Additional index words. creeping bentgrass, elemental sulfur, redox potential, sulfate, sulfatereducing bacteria, sulfide, tracer

\begin{abstract}
Black layer (BL) has reduced the quality of many putting greens since the 1980s. Initially, the nature of BL was unknown. Research established that BL was sulfide $\left(\mathrm{S}^{2-}\right)$ formed in response to low redox. Its formation was linked to dissimilative sulfate reduction using labeled sulfate $\left({ }^{35} \mathrm{SO}_{4}{ }^{2-}\right)$. The objective of this study was to see if elemental sulfur $\left(S^{0}\right)$ reduced to $S^{2-}$. When labeled sulfur $\left({ }^{35} S^{0}\right)$ with a specific activity of $3.7 \times 10^{4} \mathrm{~Bq} \cdot \mathrm{mg}^{-1}$ was added to soil from a green with $\mathrm{BL}$ in a reaction vessel kept at a low redox potential, it reduced at a per-minute rate of $5.3 \mathrm{nmol} \cdot \mathrm{cm}^{-3}$, resulting in accrual of labeled hydrogen sulfide $\left(\mathrm{H}_{2}{ }^{35} \mathrm{~S}\right)$ and acid-soluble sulfide $\left(\mathrm{AS}^{35} \mathrm{~S}\right)$. Nearly $32 \%$ of the ${ }^{35} \mathrm{~S}^{0}$ reduced to labeled sulfide $\left({ }^{35} S^{2-}\right)$ in $24 \mathrm{~h}$. Adding $S^{0}$ to greens with low redox may result in rapid formation of $\mathrm{S}^{2-}$ and an accelerated rate of $B L$ development. Avoiding this requires limiting the input of $\mathrm{S}^{0}$ or encouraging high soil redox through chemical or physical means such as fertilizing with nitrate $\left(\mathrm{NO}_{3}{ }^{-}\right)$and aerifying. This is the first report implicating $\mathrm{S}^{\mathbf{0}}$ reduction as a source of $\mathrm{BL}$ development in putting green soil.
\end{abstract}

Root-zone blackening in putting greens was termed black layer (BL) (Scott, 1986). Sometimes BL appears as a horizontal band of variable thickness, whereas other times the entire profile is blackened. A decline in turf quality usually accompanies BL. Because of its impacts on turf quality, BL can be a major problem of putting greens. It was referred to as the number one malady of creeping bentgrass (Agrostis palustris Huds.) putting greens in the late 1980s (Scott, 1986).

Black layer was determined to be an accumulation of sulfidic $\left(\mathrm{S}^{2-}\right)$ precipitates such as iron sulfide $(\mathrm{FeS})$ within the soil and plant root matrix (Berndt et al., 1987):

$$
\mathrm{S}^{2-}+\mathrm{Fe}^{2+} \rightarrow \propto-\mathrm{FeS} \downarrow \log \mathrm{K}^{\circ}=16.21
$$

This was confirmed by spot testing BL from greens at 26 golf courses in Michigan and Ohio with a solution of azide $\left(\mathrm{NaN}_{3}\right)$ and iodine $\left(I_{2}\right)$ (Berndt, 1990; Fiegl, 1972). Metal sulfides (MeS) such as FeS were present if bubbling was observed on introducing $\mathrm{BL}$ soil to solution. Bubbling occurred because $\mathrm{MeS}$ catalyzes production of $\mathrm{NaI}$ with release of $\mathrm{N}_{2}$ from solution:

$$
2 \mathrm{NaN}_{3}+\mathrm{I}_{2} \stackrel{M e S}{\longrightarrow} 2 \mathrm{NaI}+3 \mathrm{~N}_{2} \uparrow
$$

Samples of BL at all 26 courses tested positive for the presence of $\mathrm{MeS}$.

One source of sulfide $\left(\mathrm{S}^{2-}\right)$ in putting green soil containing $\mathrm{BL}$ was dissimilative reduction of $\mathrm{SO}_{4}^{2-}$ by sulfate-reducing bac-

Received for publication 30 Jan. 2008. Accepted for publication $25 \mathrm{Apr} .2008$.

${ }^{1}$ To whom reprint requests should be addressed; e-mail lberndt@edison.edu teria (SRBs) in response to low redox (Berndt and Vargas, 1987, 2006):

$$
\mathrm{SO}_{4}{ }^{2-}+8 e^{-}+8 \mathrm{H}^{+} \rightarrow \mathrm{S}^{2-} \log \mathrm{K}^{\circ}=20.7
$$

This was established using labeled sulfate $\left({ }^{35} \mathrm{SO}_{4}{ }^{2-}\right)$ (Berndt and Vargas, 2006). When $10^{-3} \mathrm{M}^{35} \mathrm{SO}_{4}{ }^{2-}$ with a specific activity (SA) of $1.554 \times 10^{5} \mathrm{~Bq} \cdot \mathrm{mg}^{-1}$ was injected into intact microcores taken from a BL in a 'Penncross' creeping bentgrass green, it reduced at a mean per-minute rate of $4.9 \times$ $10^{-3} \mathrm{nmol} \cdot \mathrm{cm}^{-3}$ (Berndt and Vargas, 2006). Labeled hydrogen sulfide $\left(\mathrm{H}_{2}{ }^{35} \mathrm{~S}\right)$ and labeled acid-soluble sulfide $\left(\mathrm{AS}^{35} \mathrm{~S}\right)$ were produced. Adding either azide $\left(\mathrm{N}^{3-}\right)$ or molybdate $\left(\mathrm{MoO}_{4}^{2-}\right)$ with the label decreased the rate to $2 \times 10^{-5}$ and $7 \times 10^{-6} \mathrm{nmol} \cdot \mathrm{cm}^{-3}$, respectively, which proved ${ }^{35} \mathrm{SO}_{4}{ }^{2-}$ reduction was biological and SRBs were involved (Berndt and Vargas, 2006).

Although tracers proved bacterial reduction of ${ }^{35} \mathrm{SO}_{4}{ }^{2-}$ occurred, other research suggested elemental sulfur $\left(\mathrm{S}^{0}\right)$ was reduced to $\mathrm{S}^{2-}$ (Berndt, 1990; Berndt and Vargas, 1992, 1996). For example, when anoxic sand was treated with $\mathrm{S}$ at $48 \mathrm{~kg} \cdot \mathrm{ha}^{-1}$ using $\mathrm{S}^{0}$ or $\mathrm{SO}_{4}{ }^{2-}$, there was $\approx 4.7$ times more $\mathrm{S}^{2-}$ produced where $\mathrm{S}^{0}$ was applied (Table 1). Differences in $\mathrm{S}^{2-}$ concentration occurred because eight electrons $\left(e^{-}\right)$are needed to reduce a molecule of $\mathrm{SO}_{4}{ }^{2-}$ to $\mathrm{S}^{2-}$, whereas only two are needed to reduce a molecule of $\mathrm{S}^{0}$ to $\mathrm{S}^{2-}$ (Lindsay, 1979):

$$
\mathrm{S}^{0}+2 e^{-}+2 \mathrm{H}^{+} \rightarrow \mathrm{S}^{2-} \log \mathrm{K}^{\circ}=15.0
$$

$$
\mathrm{SO}_{4}{ }^{2-}+8 e^{-}+8 \mathrm{H}^{+} \rightarrow \mathrm{S}^{2-} \log \mathrm{K}^{\circ}=20.7
$$

This means four times more $\mathrm{S}^{2-}$ results from reduction of $\mathrm{S}^{0}$ for a given level of reducing equivalents such as soil organic matter. This in turn implies that adding $\mathrm{S}^{0}$ to putting greens having conditions favorable for $\mathrm{BL}$ development, like low soil redox, may result in a rapid accumulation of sulfidic precipitates, hence an accelerated rate of BL formation.

Reduction of $\mathrm{S}^{0}$ occurs in many environments, and greater than 90 species of bacteria reduce $\mathrm{S}^{0}$ through enzymes like sulfur reductase (Hao and Ma, 2003; Hedderich et al., 1999; Stetter and Gaag, 1983). However, information on the reduction of $\mathrm{S}^{0}$ in soils supporting putting greens is needed, because this topic is absent in the turf literature. The objective of the research described in this article was to determine if ${ }^{35} \mathrm{~S}^{0}$ reduces to ${ }^{35} \mathrm{~S}^{2-}$ in soil from a creeping bentgrass green affected by BL.

\section{Materials and Methods}

Experimental soil. Soil with BL was collected from a 'Penncross' creeping bentgrass green at the Robert Hancock Turfgrass Research Center at Michigan State University in East Lansing. The concentration of $\mathrm{S}^{0}$ in soil was $0.19 \mathrm{mg} \cdot \mathrm{cm}^{-3}$ (Tabatabai, 1974), and most probable number estimates were $3 \times 10^{3}$ to $7 \times 10^{5} \mathrm{SRBs} / \mathrm{g}$ soil (Alexander, 1982; Berndt and Vargas, 2006). The per minute rate of ${ }^{35} \mathrm{SO}_{4}{ }^{2-}$ reduction was $4.9 \times$ $10^{-3} \mathrm{nmol} \cdot \mathrm{cm}^{-3}$ for intact cores (Berndt and Vargas, 2006) and $36.6 \times 10^{-3} \mathrm{nmols} \cdot \mathrm{cm}^{-3}$ for disturbed soil (Berndt, 1990).

Sulfide still. Recovering ${ }^{35} \mathrm{~S}^{2-}$ required an anaerobic still and $\mathrm{S}^{2-}$ trapping train, similar to the one used by Berndt and Vargas (2006) (Fig. 1). The reaction vessel was a $125-\mathrm{mL}$ Wheaton serum bottle (Wheaton Science Products, Millville, NJ) linked to an upstream source of $\mathrm{O}_{2}$-free $\mathrm{N}_{2}$ and a downstream series of ${ }^{35} \mathrm{~S}^{2-}$ traps. Oxygen was removed from the $\mathrm{N}_{2}$ stream by sparging it over hot $\mathrm{Cu}^{2+}$ filings in a Hungate apparatus (Kaspar and Tiedje, 1982). Sulfide traps were $20-\mathrm{mL}$ glass scintillation vials containing $3 \mathrm{~mL} 2 \%$ cadmium chloride $\left(\mathrm{CdCl}_{2}\right)$.

Radioactive sulfur. Elemental ${ }^{35} \mathrm{~S}^{0}$ with a SA of $3.7 \times 10^{4} \mathrm{~Bq} \cdot \mathrm{mg}^{-1}$ (Perkin-Elmer, Waltham, MA) was dissolved in benzene,

\begin{tabular}{|c|c|c|c|}
\hline & \multicolumn{2}{|c|}{$\begin{array}{c}\text { Means } \\
\left(\mathrm{mg} \cdot \mathrm{kg}^{-1}\right)\end{array}$} & \multirow{2}{*}{$\begin{array}{l}\text { Means } \\
\mathrm{p} e+\mathrm{pH}^{\mathrm{y}}\end{array}$} \\
\hline & $\mathrm{H}_{2} \mathrm{~S}$ & $\overline{\mathrm{ASS}^{2-}}$ & \\
\hline Control & 0.0 & 5.1 & 6.9 \\
\hline Sulfur $\left(\mathrm{S}^{0}\right)$ & 8.0 & 53.2 & 6.3 \\
\hline Sulfur $\left(\mathrm{S}^{0}\right)+$ & & & \\
\hline nitrate $\left(\mathrm{NO}_{3}^{-}\right)$ & 2.8 & 1.6 & 9.9 \\
\hline Sulfate $\left(\mathrm{SO}_{4}{ }^{2-}\right)$ & 5.2 & 7.8 & 6.2 \\
\hline LSD $P=0.05$ & 4.4 & 16.3 & 0.6 \\
\hline
\end{tabular}
producing a solution with a SA of $4.8 \times 10^{5}$

Table 1. Influence of sulfur on production of free hydrogen sulfide $\left(\mathrm{H}_{2} \mathrm{~S}\right)$, acid-soluble sulfide $\left(\mathrm{ASS}^{2-}\right.$ ), and redox potential as $\mathrm{pe}+\mathrm{pH}^{\mathrm{z}}$.

${ }^{2}$ Sulfur as $\mathrm{S}^{0}$ and $\mathrm{SO}_{4}{ }^{2-}$ was applied to Lake Michigan dune sand at $48 \mathrm{~kg} \cdot \mathrm{ha}^{-1}$ at Michigan State University in East Lansing. Nitrate as calcium nitrate $\left[\mathrm{Ca}\left(\mathrm{NO}_{3}\right)_{2}\right]$ was applied to provide $\mathrm{N}$ at $48 \mathrm{~kg} \cdot \mathrm{ha}^{-1}$ (from Berndt, 1990).

${ }^{\mathrm{y}}$ Redox potential as sum of measured $\mathrm{pe}$ and $\mathrm{pH}$. 


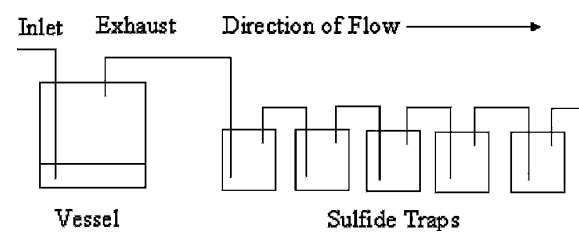

Fig. 1. Schematic of the sulfide still and trapping train used to distill labeled sulfide released from soil from a creeping bentgrass putting green affected by black layer at Michigan State University in East Lansing.

$\mathrm{Bq} \cdot \mathrm{mL}^{-1}$. The $\mathrm{SA}$ of this solution was verified by liquid scintillation counting (LSC) using a Beckman LS 8100 LSC instrument (Beckman Coulter, Fullerton, CA).

Reduction of elemental sulfur. One milliliter of the ${ }^{35} \mathrm{~S}$-benzene solution was injected into the empty reaction vessel. Benzene was evaporated by purging the bottle with $\mathrm{O}_{2}$-free $\mathrm{N}_{2}$ at a flow rate of $100 \mathrm{~cm}^{3} \cdot \mathrm{min}^{-1}$ for several minutes, leaving ${ }^{35} \mathrm{~S}^{0}$ adsorbed to the inside of the glass reaction vessel.

As purging was continued, $18 \mathrm{~cm}^{3}$ of $\mathrm{BL}$ soil was put into the vessel along with $50 \mathrm{~mL}$ of boiled, distilled water cooled to room temperature under $\mathrm{N}_{2}$. The water was amended with cysteine to establish low redox (i.e., $E_{h} \approx-340 \mathrm{mV}$ ) in the reaction vessel (Kaspar and Tiedje, 1982). Resazurin indicator was used to verify existence of low redox (Kaspar and Tiedje, 1982). The vessel opening was then plugged with butyl rubber, crimped with an aluminum seal, and the vessel was attached to both the upstream $\mathrm{O}_{2}$-free $\mathrm{N}_{2}$ gas stream and the downstream trapping train through the butyl rubber using syringe needles and Teflon tubing. Traps containing $3 \mathrm{~mL} 2 \% \mathrm{CdCl}_{2}$ were installed into the trapping train, and the flow rate of the $\mathrm{O}_{2}$-free $\mathrm{N}_{2}$ was adjusted to $100 \mathrm{~cm}^{3} \cdot \mathrm{min}^{-1}$.

If the ${ }^{35} \mathrm{~S}^{0}$ was reduced by the soil in the reaction vessel, then $\mathrm{AS}^{35} \mathrm{~S}$ precipitates (i.e., $\mathrm{Fe}^{35} \mathrm{~S}$ ) and free $\mathrm{H}_{2}{ }^{35} \mathrm{~S}$ would be produced. Any free $\mathrm{H}_{2}{ }^{35} \mathrm{~S}$ gas that evolved from the soil was swept from the reaction vessel into the trapping train with the gas stream, where it reacted with the $\mathrm{Cd}$ solution contained in the traps forming a $\mathrm{Cd}^{35} \mathrm{~S}$ precipitate (Lindsay, 1979):

$$
\mathrm{H}_{2}{ }^{35} \mathrm{~S}(\mathrm{~g})+\mathrm{CdCl}_{2} \rightarrow \mathrm{Cd}^{35} \mathrm{~S} \downarrow+2 \mathrm{HCl}
$$

Radioactivity contained in each of the traps as $\mathrm{Cd}^{35} \mathrm{~S}$ was then counted with a Beckman LS 8100 liquid scintillation counter (Beckman Coulter). Counting required addition of counting cocktail for aqueous solutions (Research Products International, Mt. Prospect, IL). All counted samples were corrected for quenching by the $\mathrm{H} \#$ method (Beckman Coulter). Traps were changed and $\mathrm{Cd}^{35} \mathrm{~S}$ was counted at $60,120,180,360,1080$, and 1440 min.

After the trap change at $1440 \mathrm{~min}, 3 \mathrm{~mL}$ $10 \% \mathrm{w} / \mathrm{v} \mathrm{NaN}_{3}$ and $2 \mathrm{~mL}$ anoxic $37 \% \mathrm{HCl}$ were injected into the reaction vessel. Azide sterilized soil, which stopped reduction of ${ }^{35} \mathrm{~S}^{0}$, and the $\mathrm{HCl}$ lowered vessel solution $\mathrm{pH}$ to $\approx 1$, which released $\mathrm{AS}^{35} \mathrm{~S}$ from soil as free $\mathrm{H}_{2}{ }^{35} \mathrm{~S}$ gas. The flow rate of $\mathrm{O}_{2}$-free $\mathrm{N}_{2}$ was once again adjusted to $100 \mathrm{~cm}^{3} \cdot \mathrm{min}^{-1}$, and the distillation was continued. Traps were changed as necessary until levels of radioactivity being swept into the trapping train with the gas stream were near background.

Calculating sulfur reduction. The perminute rate of $\mathrm{S}^{0}$ reduction was calculated using the following formula (Sorokin, 1962):

$$
\frac{(\mathrm{S})(\mathrm{a})(1.06)}{(\mathrm{A})(\mathrm{V})(\mathrm{t})}=\mathrm{nmol} \cdot \mathrm{cm}^{-3}
$$

The (S) was the concentration of $\mathrm{S}^{0}$ in the reaction vessel in nmol, (a) was $\mathrm{Bq}$ of ${ }^{35} \mathrm{~S}^{2-}$ recovered, 1.06 was an isotope correction factor, (A) was $\mathrm{Bq}$ added, (V) was soil volume $\left(\mathrm{cm}^{3}\right)$, and $(\mathrm{t})$ was the incubation time in minutes. The mean residence time $\left(t_{\mathrm{mrt}}\right)$ of the $\mathrm{S}^{0}$ pool was calculated by dividing ( $\mathrm{S}$ ) by the calculated rate of reduction, and the residence half-life of the ${ }^{35} \mathrm{~S}$ label $\left(t_{\mathrm{rhl}}\right)$ was $(\mathrm{A}) \div(\mathrm{a})(2)$ (Berndt and Vargas, 2006).

Other calculations, graphics, and statistics. The concentration of ${ }^{35} \mathrm{~S}^{2-}$ recovered $\left(\mathrm{nmol} \cdot \mathrm{cm}^{-3}\right)$ was plotted versus time to depict the release pattern of $\mathrm{H}_{2}{ }^{35} \mathrm{~S}$ over 1440 min and accrual of $\mathrm{AS}^{35} \mathrm{~S}$ in the reaction vessel during the $1440 \mathrm{~min}$. From these measurements, a first-order rate constant $(k)$ was calculated (Segel, 1976):

$$
2.3 \log \frac{[S]_{0}}{[S]}=k t
$$

In this equation, $[S]_{0}$ was the original concentration of ${ }^{35} \mathrm{~S}^{0}$ added as a percent (i.e., $100 \%)$, $[S]$ was the percentage of ${ }^{35} \mathrm{~S}^{0}$ remaining at $1440 \mathrm{~min}(t)$, and $k$ was the rate constant $\mathrm{min}^{-1}$.
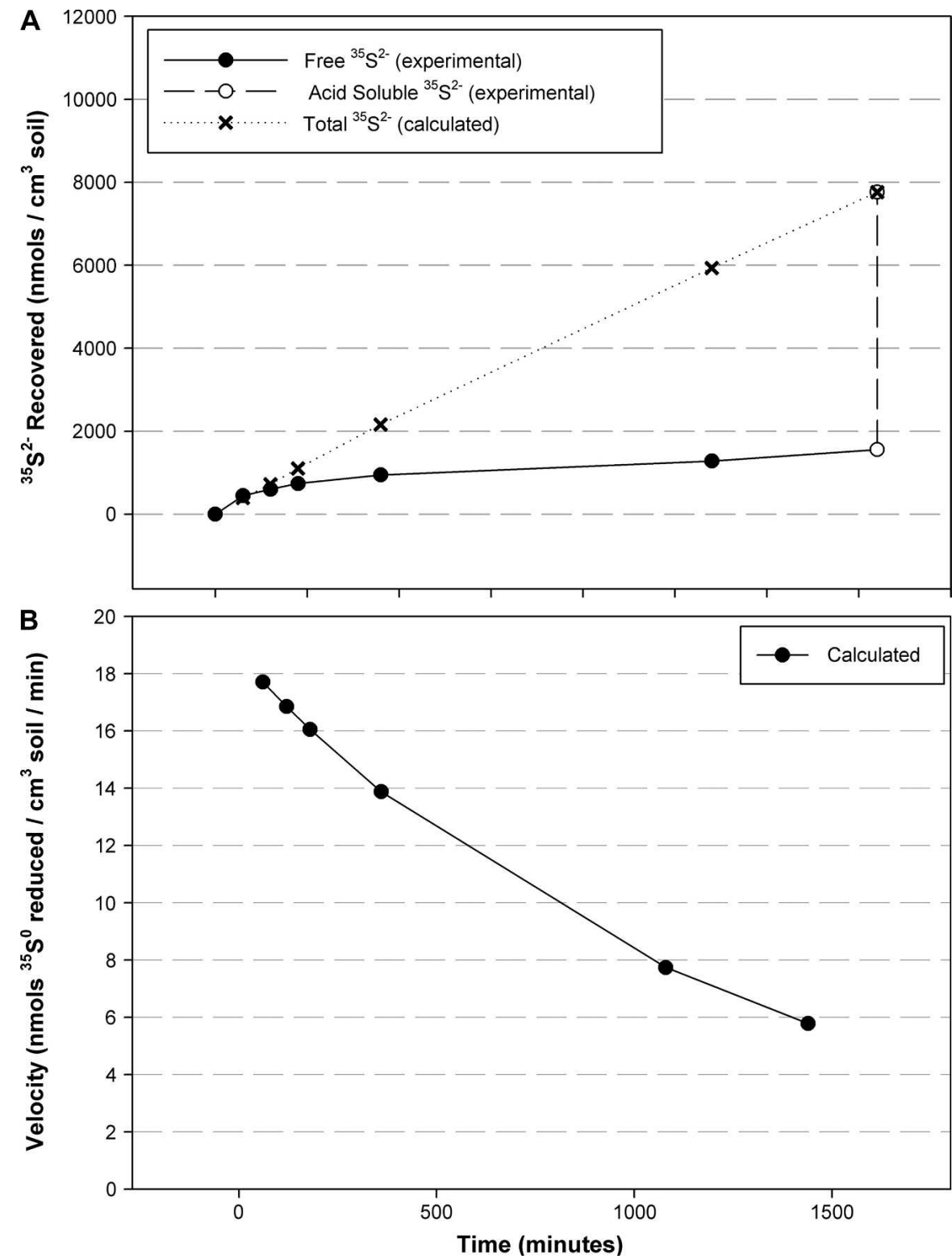

Fig. 2. (A) Time course of appearance of $\mathrm{H}_{2}{ }^{35} \mathrm{~S}$ and acid-soluble ${ }^{35} \mathrm{~S}^{2-}$ in soil from a creeping bentgrass putting green affected by black layer at Michigan State University in East Lansing. (B) Calculated velocity $(v)$ of the reduction of ${ }^{35} \mathrm{~S}^{0}$ over time. 
After $k$ was estimated, [S] was calculated for times of $60,120,180,360$, and $1080 \mathrm{~min}$ using:

$$
2.3 \log \frac{100}{[S]}=k t
$$

Subtracting $[S]$ from $[S]_{0}$ for each time gave the amount of ${ }^{35} \mathrm{~S}^{2-}$ released $\left(\mathrm{nmol} \cdot \mathrm{cm}^{-3}\right)$, which was plotted versus time. The $[S]$ at 1440 min was determined experimentally.

The velocity $(v)$ of the reduction of ${ }^{35} \mathrm{~S}^{0}$ per minute $\left(\mathrm{nmol} \cdot \mathrm{cm}^{-3}\right)$ was estimated by $v=$ $k[S]$ and plotted versus time. A plot of $v$ versus the concentration of ${ }^{35} \mathrm{~S}^{0}$ and corresponding double reciprocal plot (Segel, 1976) were developed to show the relationship between $v$ and ${ }^{35} \mathrm{~S}^{0}$.

Regression analysis was used to describe accrual of ${ }^{35} \mathrm{~S}^{2-}$ versus time, velocity of reduction versus time, and other velocity curves. Graphics and regressions were developed using SigmaPlot 10 (Steel and Torrie, 1980; Systat Software, 2006).

\section{Results}

Radioactive ${ }^{35} \mathrm{~S}^{2-}$ was trapped with no apparent lag time (Fig. 2A). Approximately $31.5 \%$ of ${ }^{35} \mathrm{~S}^{0}$ was recovered as ${ }^{35} \mathrm{~S}^{2-}$ with the ratio of total ${ }^{35} \mathrm{~S}^{2-}$ trapped to $\mathrm{H}_{2}{ }^{35} \mathrm{~S}$ trapped being 4.95. The $\mathrm{H}_{2}{ }^{35} \mathrm{~S}$ trapped over $1440 \mathrm{~min}$ was $6.4 \%$ of the added label, or $20.2 \%$ of trapped ${ }^{35} \mathrm{~S}^{2-}$. The $\mathrm{AS}^{35} \mathrm{~S}$ liberated by $\mathrm{HCl}$ was $25.2 \%$ of the added label, or $79.8 \%$ of trapped ${ }^{35} \mathrm{~S}^{2-}$. The per-minute rate of $\mathrm{S}^{0}$ reduction was $5.3 \mathrm{nmols} \cdot \mathrm{cm}^{-3}$. The $t_{\mathrm{mrt}}$ of the $\mathrm{S}^{0}$ pool was $77,900 \mathrm{~min}$ and the $t_{\text {rhl }}$ of the label was $2304 \mathrm{~min}$.

The $k$ at 1440 min was $8.1 \times 10^{-4}$ per min. Velocity $(v)$ of the reduction of ${ }^{35} \mathrm{~S}^{0}$ decreased with time in curvilinear style $\left(\mathrm{R}^{2}=\right.$ $0.9998 ; \hat{\mathrm{Y}}=18.4-0.137 \mathrm{X}+3.0 \times 10-6 \mathrm{X}^{2}$ ) (Fig. 2B). The per-minute $v$ at $1440 \mathrm{~min}$ of $5.77 \mathrm{nmol} \cdot \mathrm{cm}^{-3}$ was very close to the rate of $5.33 \mathrm{nmol} \cdot \mathrm{cm}^{-3}$ calculated using Sorokin's (1962) formula. When $v$ was plotted versus concentration of ${ }^{35} \mathrm{~S}^{0}$ (Fig. 3A), the curve was linear $\left(\mathrm{R}^{2}=1.0 ; \hat{\mathrm{Y}}=-0.0023+0.0008 \mathrm{X}\right)$, which meant $v$ was proportional to concentration of ${ }^{35} \mathrm{~S}^{0}$. When plotted as a Lineweaver-Burk plot (Fig. 3B), the curve intercepted both axes too closely to the origin to determine either maximum velocity (i.e., $V_{\max }$ ) or the Michaelis constant (i.e., $K_{m}$ ). This meant that enzyme saturation did not occur, $V_{\max }$ and $K_{m}$ appeared infinite, and the reaction was first order.

\section{Discussion}

Understanding the reduction of $\mathrm{S}^{0}$ is important, because $\mathrm{S}^{0}$ is recommended for turf in a variety of publications (Beard, 1973; Landschoot, 2007; Vargas, 2005; Voight et al., 2007). Sulfur can be used to help mitigate alkaline soil conditions and offset $\mathrm{S}$ deficiency (Beard, 1973; Vargas, 2005). It has also been used to try to prevent encroachment of annual bluegrass (Poa annua L.) into greens (Joseph Vargas, personal communication). Conversely, the negative consequence

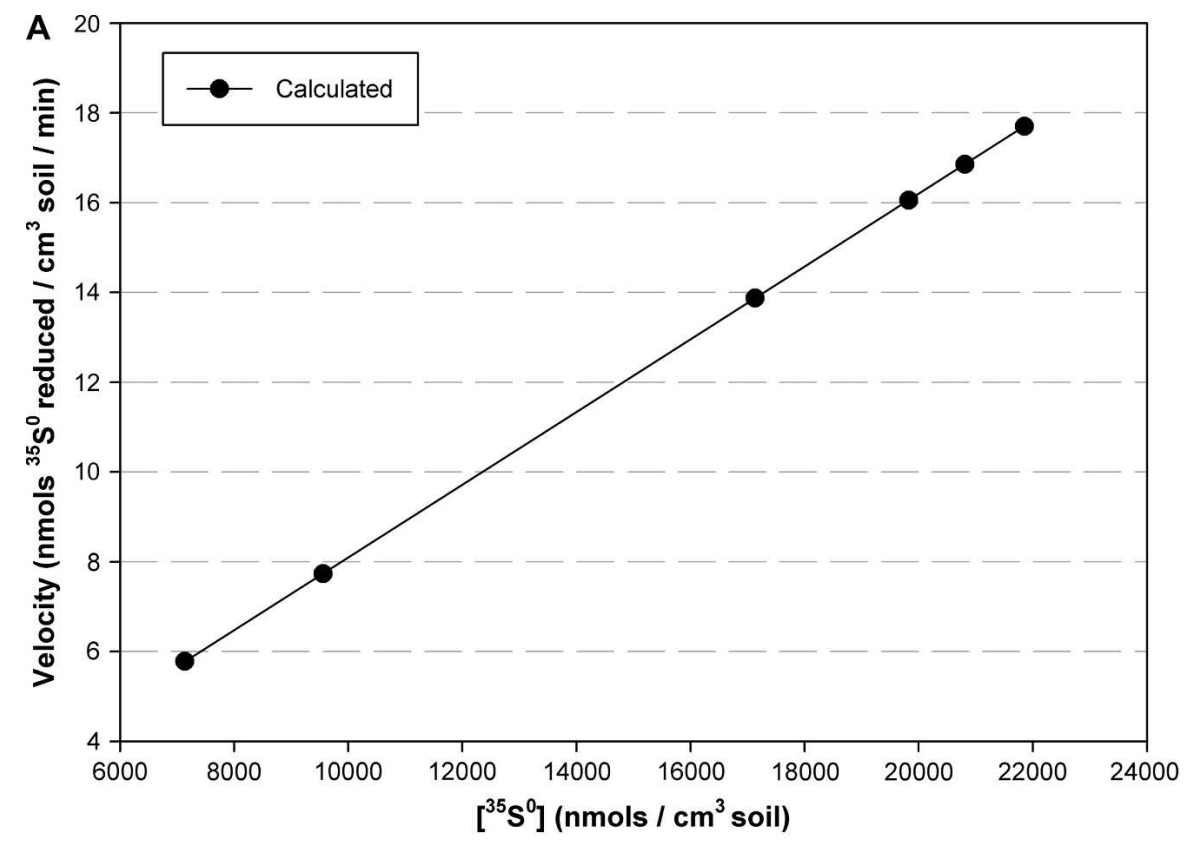

B

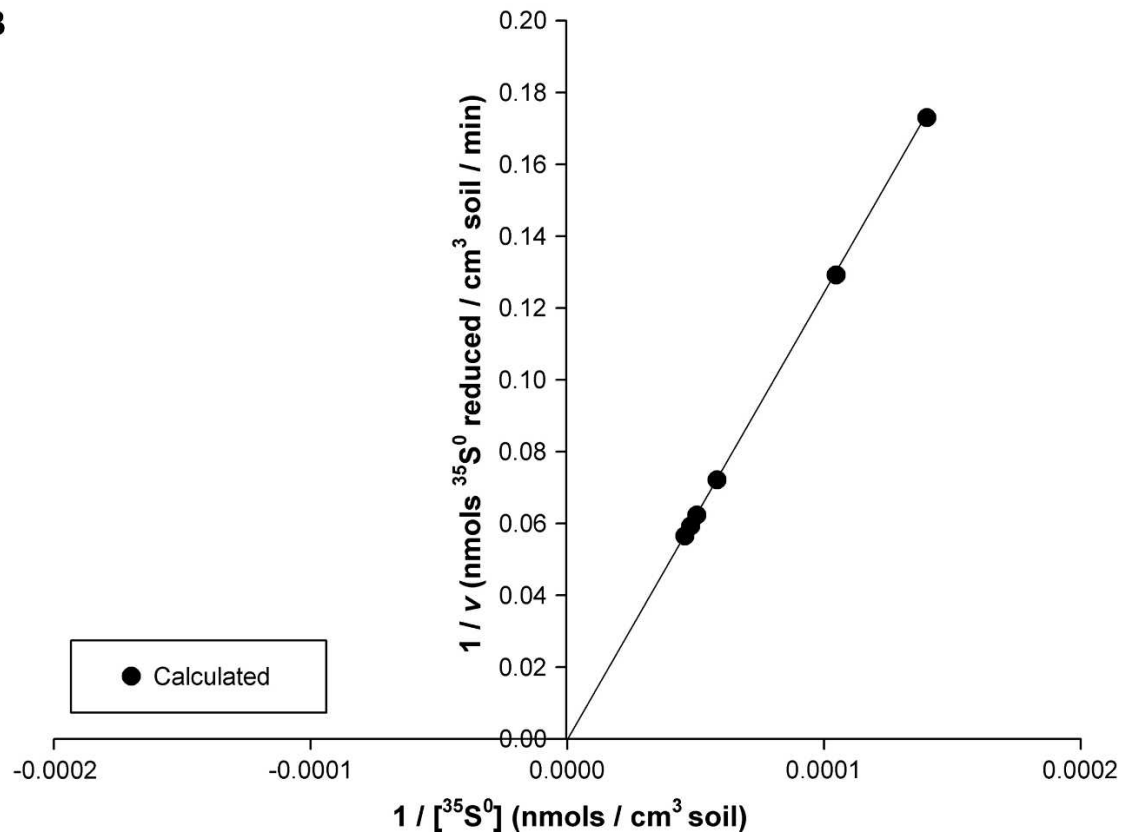

Fig. 3. (A) Velocity of reduction of ${ }^{35} \mathrm{~S}^{0}$ as a function of its concentration in soil from a creeping bentgrass putting green affected by black layer at Michigan State University in East Lansing. (B) Data presented as a Lineweaver-Burk double reciprocal plot.

of applying $\mathrm{S}^{0}$, especially in relation to its reduction, has not been adequately addressed in the turfgrass management literature.

Applying $\mathrm{S}^{0}$ can help to generate and perpetuate favorable environmental conditions for release of $\mathrm{S}^{2-}$ to soil, hence BL formation (Berndt and Vargas, 1992). These include low redox and abundant $\mathrm{S}$. Consider that applying $\mathrm{S}^{0}$ to soil increases acidity through microbial oxidation of $\mathrm{S}^{0}$ to $\mathrm{H}_{2} \mathrm{SO}_{4}$ :

$$
\mathrm{S}^{0}+3 / 2 \mathrm{O}_{2}+\mathrm{H}_{2} \mathrm{O} \rightarrow \mathrm{H}_{2} \mathrm{SO}_{4}
$$

This reaction is widely known, but what has not been emphasized is this process consumes $\mathrm{O}_{2}$ and increases $\mathrm{H}^{+}$thereby reducing redox potential as $\mathrm{pe}+\mathrm{pH}$ (Berndt and Vargas, 1992).
Oxidation of $\mathrm{S}^{0}$ is obviously not the only source of low redox in soils. It is well known that water-logging and the presence of restrictive layers in soil can exclude diffusion of $\mathrm{O}_{2}$ and in turn generate low redox. Excessive microbial respiration can also cause low redox. The point is, however, that once low redox exists, and provided $\mathrm{S}^{0}$ is abundant, as when it is applied to greens, the formation of $\mathrm{S}^{2-}$ through $\mathrm{S}^{0}$ reduction may occur rapidly, and the rate of $\mathrm{BL}$ formation and development may be accelerated. In the current research introducing $\mathrm{S}^{0}$ and cysteine into the reaction vessel and continually purging it with $\mathrm{O}_{2}$-free $\mathrm{N}_{2}$ generated favorable environmental conditions for formation of $\mathrm{S}^{2-}$, a redox potential of $\approx-340 \mathrm{mV}$ (Kaspar 
and Tiedje, 1982), and plenty of $\mathrm{S}^{0}$ to be reduced.

Avoiding an accelerated rate of BL formation in putting greens requires limiting input of $\mathrm{S}^{0}$ and sustaining high soil redox potential through chemical or physical means such as fertilizing with nitrate $\left(\mathrm{NO}_{3}{ }^{-}\right)$and aerifying.

\section{Literature Cited}

Alexander, M. 1982. Most probable number method for microbial populations, p. 815820. In: Page, A.L. (ed.). Methods of soil analysis. Part 2. 2nd Ed. Agron. Monogr. 9. ASA and SSSA, Madison, WI.

Beard, J. 1973. Turfgrass: Science and culture. Prentice-Hall, Englewood Cliffs, NJ.

Berndt, W.L. 1990. Investigation into turfgrass black layer. Michigan State Univ., East Lansing. PhD Diss. Abstr. 51-12B. p. 5673.

Berndt, W.L. and J.M. Vargas, Jr. 1987. Etiology and impact of dissimilatory sulfate reduction in highly maintained turfgrass soils. Phytopathology 77:1716.

Berndt, W.L. and J.M. Vargas, Jr. 1992. Elemental sulfur lowers redox potential and produces sulfide in putting green sand. HortScience 27:1188-1190.
Berndt, W.L. and J.M. Vargas, Jr. 1996. Preventing black layer with nitrate. J. Turfgrass Management. 1:11-22.

Berndt, W.L. and J.M. Vargas, Jr. 2006. Dissimilatory reduction of sulfate in black layer. HortScience 41:815-817.

Berndt, W.L., J.M. Vargas, Jr., A.R. Detweiler, P.E. Rieke, and B.E. Branham. 1987. Black layer formation in highly maintained turfgrass soils. Golf Course Mgt. 55:106-112.

Feigl, F. 1972. Spot tests in inorganic analysis. Elsevier, Amsterdam, The Netherlands.

Hao, X. and K. Ma. 2003. Minimal sulfur requirement for growth and sulfur-dependent metabolism of the hyperthermophilic archaeon Staphylothermus marinus. Archaea 1:191-197.

Hedderich, R., O. Klimmek, A. Kroger, R. Dirmeier, M. Keller, and K.O. Stetter. 1999. Anaerobic respiration with elemental sulfur and with disulfides. FEMS Microbiol. Rev. 22:353-381.

Kaspar, H.F. and J.M. Tiedje. 1982. Anaerobic bacteria and processes, p. 989-1009. In: Page, A.L. (ed.). Methods of soil analysis. Part 2. 2nd Ed. Agron. Monogr. 9. ASA and SSSA, Madison, WI.

Landschoot, P. 2007. Managing soil $\mathrm{pH}$ in turf. Grounds Maintenance, Penton Media, Inc. 21 Nov. 2007. <http://grounds-mag.com/mag/ grounds_maintenance_managing_soil_ph_2/ index.html>.
Lindsay, W.L. 1979. Chemical equilibria in soils. Wiley, New York, NY.

Scott, J. 1986. The black plague. Golf Course Mgt. 54:58-64.

Segel, I.H. 1976. Biochemical calculations. Wiley, New York, NY.

Sorokin, Y.I. 1962. Experimental investigation of bacterial sulfate reduction in the Black Sea using 35S. Transl. Microbiology 31:329335.

Steel, R.G.D. and J.H. Torrie. 1980. Principles and procedures of statistics: A biometrical approach. McGraw-Hill, New York, NY.

Stetter, K.O. and G. Gaag. 1983. Reduction of molecular sulphur by methanogenic archaea. Nature 305:309-311.

Systat Software. 2006. SigmaPlot 10 users manual. Systat Software, Inc., Point Richmond, CA.

Tabatabai, M.A. 1974. Determination of sulfate in water samples. Sulfur Inst. J. 10:11-13.

Vargas, J.M. 2005. Management of turfgrass diseases. Wiley, Hoboken, NJ.

Voight, T., T. Fermanian, and D. Wehner. 2007. Turfgrass fertilization. College of Agriculture, Consumer, and Environmental Science, University of Illinois at Urbana-Champagne. 21 Nov. 2007. <http://www.turf.uiuc.edu/ extension/ext-fert.html $>$. 